\title{
Examining the effect of relationship marketing on the frequency of using banking services
}

\author{
Behrooz Golnarian* and Hamed Hagh Talab
}

Department of Management, Torbat-e-Jam Branch, Islamic Azad University, Torbat-e-Jam, Iran

\section{CHRON I C L E ABSTRACT}

Article history:

Received 5 January 2014

Received in revised format 8 March 2014

Accepted 14 March 2014

Available online

16 March 2014

Keywords:

Relationship marketing

Trust

Communication

Conflict-handling

Commitment

\begin{abstract}
The purpose of this study was to examine the effect of relationship marketing on customers' frequent use of services provided by an Iranian bank named Eghtesad Novin (EN). The present study was a correlational-applied study. The population of this study was all customers who had more than two years of collaboration with the EN Bank and were living in Tehran. Therefore, those branches located in diverse districts of Tehran were selected from all branches across the country. Since each branch was associated with one of quadripartite districts, five branches were selected randomly from each district. Multi-phase cluster random sampling was carried out in these districts. To obtain a sample size, formula of ratio estimation with a relative error of 0.05 and a maximum variance value of 0.50 were used so that the total size of sample was determined as 400 approximately. This study utilized the descriptive survey method. For this purpose, researcher-made questionnaires were used. In order to determine the reliability of the above-mentioned questionnaires, Cronbach's alpha coefficient was used and it was determined as 0.813 , which confirmed the questionnaires. In addition, the validity of these questionnaires was reviewed and confirmed using expert opinions and viewpoints of professionals working in the banking sector as well as respectful professors. Inferential statistics as well as SPSS and LISREL software were used in order to design the research model. To this end, the effect of the foundation of relationship marketing including commitment, trust, communication and conflict-handling on customer loyalty, the importance of these factors from the perspective of the customers and the bank's success in creating any of the variables was examined and the data was analyzed using multiple regression method. The results showed that, except commitment, other foundations of relationship marketing had significant and positive effects in this bank.
\end{abstract}

(C) 2014 Growing Science Ltd. All rights reserved.

\section{Introduction}

During the past few years, there have been tremendous changes on banking industry in the world and many banks with different business model have appeared on the market (Kotler \& Armstrong, 2010; Zineldin \& Philipson, 2007). The business environment of the 1990s has seen a shift in firms' emphasis away from recruiting new customers, towards nurturing and retaining those that they currently have (Palmer, 1996). Therefore, there is a need to have a look at banks' programs and *Corresponding author.

E-mail addresses: b.golnarian@yahoo.com (B. Golnarian) 
develop new methods for customer retention and absorption. Ehigie (2006) examined how customer expectations, perceived service quality and satisfaction predict loyalty among bank customers in Nigeria. He reported that perception of service quality and satisfaction were significant predictors of customer loyalty, with customer satisfaction contributing more. Grönroos (2004) presented a framework of central processes in relationship marketing, which included an interaction process as the core, a planned communication process as the marketing communications support through distinct communications media, and a customer value process as the outcome of relationship marketing. Sin et al. (2005) addressed the conceptual and measurement issues associated with the study of relationship marketing orientation (RMO). They first reviewed the concept of RMO and its relative important components and then reported on the construction and psychometric assessment of a measure of RMO. They developed six multi-item scales indicating strong evidence of reliability and validity in samples from firms in Mainland China and Hong Kong. They also provided evidence supporting scale invariance across the two samples. Payne and Frow (2005) developed a conceptual model for customer relationship management (CRM) to investigate the role in enhancing customer value. They explored definitional characteristics of CRM, and identified three alternative perspectives of CRM. They focused on the need for a cross-functional, process-oriented approach that positions CRM at a strategic level. They determined five key cross-functional CRM processes including a strategy development process, a value creation process, a multichannel integration process, an information management process, and a performance assessment process.

\section{Research Methodology}

The purpose of this study is to examine the impact of relationship marketing on the customers' frequent use of banking services in diverse branches of EN Bank across Tehran city. Regarding the purpose of research, this study is of applied type. Furthermore and regarding the nature of research, this study is of descriptive nature, which has been done in survey method. Besides, this study has been placed in quantitative category. The population of this study covered all customers who had more than two years of collaboration with EN Bank and they were living in Tehran. The reasons for choosing this population were because a significant numbers of the customers resided in this city and they could make change in the marketing world. Therefore, branches located in Tehran were selected from all branches across the country. Since each branch was associated with one of these quadripartite districts of this bank, five branches were selected randomly from each district. Multiphase cluster random sampling has been carried out in these districts. To obtain samples for determining the sample size required to estimate the desired parameter, one must calculate the permissible error in the estimation of the parameter. The sample size is calculated as follows, $N=Z_{\alpha / 2}^{2} \frac{p \times q}{e^{2}}$,

where $N$ is the sample size, $p=1-q$ represents the probability, $z_{\alpha / 2}$ is CDF of normal distribution and finally $\varepsilon$ is the error term. For our study we assume $p=0.5, z_{\alpha / 2}=1.96$ and $e=0.05$, the number of sample size is calculated as $N=384$ and the proposed study of this paper distributed 400 questionnaires among some randomly selected customers. Regarding primary and secondary data, the researcher made use of questionnaires, interviews and document (text) mining as the main data collection tools. For this purpose, a researcher-made questionnaire was used, which had two sections: general questions and specific questions. General questions included gender, level of education and work experience. Specific questions, which constituted the second part of the questionnaire and intended to measure trust, communication, commitment, and conflict-handling, were framed into 22 questions with 5 options. In order to measure the reliability of these questionnaires, the Cronbach's Alpha was performed using SPSS software. For this purpose, an initial sample included 40 questionnaires was collected. Using the data obtained from the questionnaires and SPSS software, reliability coefficient was determined by Cronbach's alpha technique. Cronbach's alpha coefficient for the total questionnaire was determined as 0.813 , which was an acceptable value. In addition, the 
validity of these questionnaires was reviewed and confirmed using experts' opinions and viewpoints of professionals working in the banking sector as well as respectful professors. In order to measure the content validity of the questionnaire, a specific questionnaire along with its index and components was delivered to 10 experts and they examined the questionnaires. Then, using the Lawshe formula (Lawshe, 1975), it was found whether specific items were basic and appropriate or not. Furthermore, questions that had coefficients higher than 0.62 were accepted. The dependent variable in this study was the frequency of using of banking services, which indicated the customer loyalty within a specific time. This variable was assessed via questions 19 to 22 . Independent variables were as follow:

Trust: it indicated the extent to which a respondent trusted to bank and banking operations and believed in it and thought that it was appropriate and proper. This variable was assessed via questions 1 to 4 .

Commitment: It was when a person felt committed and responsible towards behaviors and actions.

Communication: It was an established communication between customers and bank, which was assessed via questions 10 to 14 .

Conflict-handling: Questions 15 to 18 assessed the impact of conflict-handling between the customer and the bank.

In this regard, the research hypotheses were proposed as follows:

1. The level of trusting influences the frequency of using of banking services.

2. Communication between bank and customers influences the frequency of using of banking services.

3. Commitment between bank and customers influences the frequency of using of banking services.

4. Conflict-handling between bank and customers influences the frequency of using of banking services.

Inferential statistics as well as SPSS and LISREL software were used in order to design the research model. To this end, the effect of the foundation of relationship marketing including commitment, trust, communication and conflict management on customer loyalty, the importance of these factors from the perspective of the customers and the bank's success in creating any of the variables was examined. Then, data were analyzed using multiple regression method and the relationship between variable were examined thereof.

\section{Results}

Among the respondents to the questionnaire, $43.0 \%$ were female and $57.0 \%$ were male. Also, in terms of age, $24.3 \%$ were between 18 and 25 years, $57.3 \%$ were between 26 to 35 years, $15.8 \%$ were between 36 and 50 years and $2.8 \%$ were older than 50 years. In terms of education level, $4.0 \%$ had educational levels lower than diploma, $26.0 \%$ had diploma or Associate Degree, $60.5 \%$ had bachelor degree and $9.5 \%$ had master's degree and higher. Regarding term relationship with the bank, 39.5\% had more than 4 years of relationship, $44.8 \%$ had between 4 to 6 years of relationship, $12.3 \%$ had between 7 to 9 years of relationship, and $3.5 \%$ had 10 years of relationship and more.

\section{Table 1}

Descriptive statistics for mean scores of indicators

\begin{tabular}{lcccc}
\hline Indicator & Min & Max & Mean & Std. Dev. \\
\hline Customer's trust to the bank & 3.00 & 5.00 & 4.4181 & 0.39698 \\
Commitment between customers and the bank & 2.80 & 5.00 & 4.2185 & 0.41616 \\
Establishment of communication between the bank and customers & 3.20 & 5.00 & 4.1725 & 0.43729 \\
Conflict-handling between the bank and customers & 2.25 & 5.00 & 4.1212 & 0.49684 \\
Frequency of using of banking services & 2.50 & 5.00 & 3.9356 & 0.56034 \\
\hline
\end{tabular}


Regarding the indicators ( $\mathrm{n}=400$ samples), customer's trust to the bank ranked first followed by commitment between customers and the bank, communication between the bank and customers, conflict-handling between the bank and customers and frequency of using of banking services.

\section{Data analysis}

Using Kolmogorov-Smirnov test, it was concluded that variables of customer's trust to the bank, commitment between customers and the bank, communication between the bank and customers, conflict-handling between the bank and customersand frequency of using of banking services were not normally distributed. Due to abnormality of variables and in order to evaluate the relationship between the independent variables ofcustomer's trust to the bank, commitment between customers and the bank, communication between the bank and customers, conflict-handling between the bank and customerswith the dependent variable offrequency of using of banking services, we used singlesample Z-test.

Furthermore and in order to evaluate the impacts of the independent variables of customer's trust to the bank, commitment between customers and the bank, communication between the bank and customers, conflict-handling between the bank and customers on the dependent variable of frequency of using of banking services (hypotheses 1, 2, 3, and 4 hypotheses), we have used multiple linear regression technique. Regarding the multiple linear regression, we first tried to confirm the research model via using ANOVA (linear regression), Durbin-Watson (Serial Correlation LM), Kolmogorov Smirnov (normality of residuals) and non-linearity. Using non-standardized coefficients, we obtained regression equation. We have used this equation to predict the dependent variable from the independent variables. Finally and using standardized coefficients, we have obtained the effect of each independent variable on the dependent variable and did path analysis.

Table 2

The summary of the results of one-sample Z-test to check the indicators

\begin{tabular}{|c|c|c|c|c|c|}
\hline Variable & $\begin{array}{c}\text { Significance } \\
\text { level }\end{array}$ & $\begin{array}{c}\text { Value of } \\
\text { error }\end{array}$ & $\begin{array}{c}\mathrm{T} \\
\text { statistics }\end{array}$ & $\begin{array}{c}\text { Confirming the } \\
\text { hypothesis }\end{array}$ & Conclusion \\
\hline Customer's trust to the bank & 0.000 & 0.05 & 28.36 & $\mathrm{H}_{1}$ & $\mu>3$ \\
\hline Commitment between customers and the bank & 0.000 & 0.05 & 24.37 & $\mathrm{H}_{1}$ & $\mu>3$ \\
\hline Establishment of communication between the bank and customers & 0.000 & 0.05 & 23.45 & $\mathrm{H}_{1}$ & $\mu>3$ \\
\hline Conflict-handling between the bank and customers & 0.000 & 0.05 & 22.42 & $\mathrm{H}_{1}$ & $\mu>3$ \\
\hline Frequency of using of banking services & 0.000 & 0.05 & 18.71 & $\mathrm{H}_{1}$ & $\mu>3$ \\
\hline
\end{tabular}

If the significance level was larger than the value of error (0.05), we would adopt the null hypothesis and if the significance level was less the value of error (0.05), we would adopt H1 (if the Z-statistic was greater than $1.64, \mathrm{H}_{1}$ would be confirmed). According to the results obtained from the Table 2, all the indicators were in good positions.

Table 3

Test of the significance of coefficients

\begin{tabular}{lcccc}
\hline Indicator & $\begin{array}{c}\text { Significance } \\
\text { level }\end{array}$ & T-statistic & $\begin{array}{c}\text { Standard } \\
\text { coefficient }\end{array}$ & $\begin{array}{c}\text { Non-standard } \\
\text { coefficient }\end{array}$ \\
\hline Customer's trust to the bank & 0.000 & 6.380 & 0.305 & 0.430 \\
Commitment between customers and the bank & 0.179 & 1.347 & 0.067 & 0.090 \\
Establishment of communication between the bank and customers & 0.000 & 5.008 & 0.239 & 0.306 \\
Conflict-handling between the bank and customers & 0.000 & 3.714 & 0.176 & 0.198 \\
\hline
\end{tabular}

Based on the results of Table 3, we can conclude that,

- Since the significant level was 0.000 and less than error value of 0.05 (absolute value of t-statistic was greater than 1.96 ), we adopted the $\mathrm{H}_{1}$ with $95 \%$ confidence. So, the variable of customer's trust to the bankremained in the model and its coefficient equaled to 0.430. Furthermore, we concluded 
that the customer's trust to the bank had a significant and positive effect ( 30.5 percent) on the frequency of using of banking services.

- Since the significant level was 0.179 and greater than error value of 0.05 (absolute value of tstatistic was less than 1.96), we adopted the null hypothesis with $95 \%$ confidence. So, the variable of commitment between customers and the bank was deleted from the model. Furthermore, we concluded that the commitment between customers and the bank did not have any significant effect on the frequency of using of banking services.

- Since the significant level was 0.000 and less than error value of 0.05 (absolute value of t-statistic was greater than 1.96), we adopted the $\mathrm{H}_{1}$ with 95\% confidence. Therefore, the variable of establishment of communication between the bank and customers remained in the model and its coefficient equaled to 0.306 . Furthermore, we concluded that the establishment of communication between the bank and customers had a significant, positive and direct effect (23.9 percent) on the frequency of using of banking services.

- Since the significant level was 0.000 and it was less than error value of 0.05 (absolute value of $t$ statistic was greater than 1.96), we adopted the $\mathrm{H}_{1}$ with $95 \%$ confidence. Therefore, the variable of conflict-handling between the bank and customers remained in the model and its coefficient equaled to 0.198 . Furthermore, we concluded that the conflict-handling between the bank and customers had a significant and positive direct effect (17.6 percent) on the frequency of using of banking services.

\section{Discussion and conclusion}

The purpose of this study was to examine the effect of relationship marketing on customers' frequent use of services provided by EN Bank in city of Tehran, Iran. Since relationship marketing is a new paradigm in the field of marketing, many scholars have commented on the foundations of relationship marketing. In addition, there is a high sensitivity of relationship marketing to cultural, economic, and social factors and foundations of relationship marketing are somewhat different. Hence, this study have tried to identify the foundations of relationship marketing in the economic, social, and cultural environments available in EN Bank branches. The collected data were classified and categorized and then, were analyzed using descriptive indicators. In addition, using non-parametric as well as inferential statistical techniques, hypotheses were tested. Finally, SPSS software was used in order to analyze and interpret the data.

The results of the research hypotheses:

The first research hypothesis: Using statistical analyses, the effect of the customer's trust to the bank on frequency of using of banking services was confirmed. Confirming the first hypothesis means that if banks can obtain customers' trust and loyalty towards providing banking services, they can be sure about achieving frequent use of services on part of customers. The results indicate that customers pay high attention to factors that can obtain their trust to bank. Bank customers expect banks to guarantee the safety of their bank accounts and deliver high-quality services consistently.

The second research hypothesis: One essential condition for the creation of customer loyalty is establishment of commitment within them. According to the results, although commitment is considered as one of the important elements in relationship marketing, the results have not shown a significant relationship between them and the role of these elements in these samples are shown less important. As a result, its impact on frequency of customer's using of services of EN Bank has a lower importance.

The third research hypothesis: Today, due to the competition among Iranian banks, bank customers are demanding immediate and continuous services through which banks can contact with them in 
several ways to provide essential information. Providing useful information on behalf of bank, innovation in providing services and effective communication as well as changing the types of services will provide required information to customers. According to the study results, the relationship or relationships of customers with banks has a positive effect on the frequency of using of services.

The fourth hypothesis: As the results of the test indicate, conflict-handling between customers and the bank has a positive impact on frequency of using of banking services. Conflict is one of the issues that may occur between supplier of goods and services and customers. Naturally, suppliers of goods and services try to avoid having any conflict. They need to try to remove it after it happened. Banks are not excluded from this rule. If the banks' customers were having difficulty, they would probably lose their customers. Finally, the present findings suggest that customer's trust to the bank, communication between the bank and customers, and conflict-handling between the bank and customers play essential role on the frequency of using of banking services and that the only exception in this field is commitment. These findings are aligned with researches conducted by Reichheld and Sasser (2010).

What is certain is that the debate on all aspects of this subject, despite its considerable size, is important. Each of these factors can explain part of the reasons for the effect of relationship marketing on frequency of using of banking services. Other part of these factors can be helpful in order to pave the way for more development and participation of managers and improve their attitude toward frequent use of banking services. The above-mentioned issue should be taken into consideration. Based on the results of the survey, we recommend enhancing the security of customer accounts to increase customers' trust. We also recommend establishment of good communication and responsiveness to help bank owners actualize the motto of customer centricity to a real practice. Banks' representatives need to pay enough attention to relationship marketing in the domain of banks.

\section{Acknowledgement}

The authors would like to thank the anonymous referees for the comments on the earlier version of this paper.

\section{References}

Ehigie, B. O. (2006). Correlates of customer loyalty to their bank: a case study in Nigeria. International Journal of Bank Marketing, 24(7), 494-508.

Grönroos, C. (2004). The relationship marketing process: communication, interaction, dialogue, value. Journal of Business \& Industrial Marketing, 19(2), 99-113.

Kotler, P., \& Armstrong, G. (2010). Principles of Marketing. Pearson Education.

Lawshe, C.H. (1975). A quantitative approach to content validity. Personnel Psychology, 28, 563575.

Payne, A., \& Frow, P. (2005). A strategic framework for customer relationship management. Journal of marketing, 69(4), 167-176.

Reichheld, F., \& Sasser, W. (2010). Zero defections: quality comes to services. Harvard Business Review, 105-11.

Palmer, A. J. (1996). Relationship marketing: a universal paradigm or management fad?. Learning Organization, 3(3), 18-25.

Sin, L. Y., Tse, A. C., Yau, O. H., Chow, R. P., Lee, J. S., \& Lau, L. B. (2005). Relationship marketing orientation: scale development and cross-cultural validation. Journal of Business Research, 58(2), 185-194.

Zineldin, M., \& Philipson, S. (2007). Kotler and Borden are not dead: myth of relationship marketing and truth of the 4Ps. Journal of consumer marketing,24(4), 229-241. 